\title{
Penetration of cefaclor into bronchial mucosa
}

\author{
GE MARLIN, AJ NICHOLLS, GR FUNNELL, R BRADBURY \\ From the Respiratory Investigation Unit and the Department of Microbiology, Concord Hospital, Sydney, \\ Australia
}

ABSTRACT Bronchial mucosal biopsy specimens were obtained during fibreoptic bronchoscopy in 30 patients receiving a new oral cephalosporin antibiotic, cefaclor $(10 \mathrm{had} 250 \mathrm{mg}, 10 \mathrm{had} 500$ $\mathrm{mg}$, and $10 \mathrm{had} 1000 \mathrm{mg}$ every eight hours). In 10 patients (from all dosage groups) cefaclor was undetectable in the bronchial mucosa but in every case the serum concentration was low, suggesting incomplete absorption. The mean (SD) bronchial mucosal concentration after $250 \mathrm{mg}$ was 3.78 (1.77) $\mu \mathrm{g} / \mathrm{g}$ (range $2.1-5.8 \mu \mathrm{g} / \mathrm{g}, \mathrm{n}=4)$, after $500 \mathrm{mg} 4.43(2.04) \mu \mathrm{g} / \mathrm{g}$ (range 2.0-7.1 $\mu \mathrm{g} / \mathrm{g}, \mathrm{n}=8$ ), and after $1000 \mathrm{mg} 7.73(2.76) \mu \mathrm{g} / \mathrm{g}$ (range $5.0-12.7 \mu \mathrm{g} / \mathrm{g}, \mathrm{n}=6$ ). A significantly higher concentration in the bronchial mucosa was achieved with $1000 \mathrm{mg}$ than with $250 \mathrm{mg}$ (p< $0.05)$ or $500 \mathrm{mg}(\mathrm{p}<0.025)$. These concentrations should be effective against Streptococcus pneumoniae, most strains being inhibited below $1.0 \mu \mathrm{g} / \mathrm{ml}$. The concentrations were within one dilution of the minimal inhibitory concentration for Haemophilus infuenzae, most strains being inhibited below $4.0 \mu \mathrm{g} / \mathrm{ml}$. Some strains of $H$ infuenzae will not be inhibited by the concentrations of cefaclor found in the bronchial mucosa, particularly those that are ampicillin resistant.

Cefaclor is a new oral cephalosporin antibiotic that possesses more activity than cephalexin in vitro against certain organisms, including Haemophilus infuenzae, Klebsiella pneumoniae, and Escherichia coli. ${ }^{1-3}$ The most common infecting organisms causing acute bronchial infection in patients with chronic bronchitis are $H$ infuenzae and Streptococcus pneumoniae. ${ }^{4}$ In recent years several reports have indicated an increasing incidence of the resistance of $H$ infuenzae to ampicillin, the prevalence rate being 5-10\%. This resistance, which may result in treatment failure, is usually ascribed to $\beta$-lactamase enzyme production, but there may also be a degree of inherent resistance. ${ }^{5}$ Cefaclor retains greater activity against ampicillin resistant $H$ infuenzae than the first generation cephalosporins. ${ }^{26}$

Early clinical studies have indicated that cefaclor is effective in acute bronchitis and pneumonia caused by susceptible organisms. ${ }^{7-9}$ The purpose of this study was to evaluate the penetration of cefaclor into bronchial mucosa and to compare the concentrations achieved with the in vitro antibacterial activity of the antibiotic.

Address for reprint requests: Dr GE Marlin, Respiratory Investigation Unit, Concord Hospital, Concord 2139, New South Wales, Australia.

Accepted 30 May 1984

\section{Methods}

PATIENTS AND STUDY DESIGN

Thirty patients ( 28 men and two women aged 25-82 years) who were having fibreoptic bronchoscopy for investigation of pulmonary disease were selected for this study. Informed, written consent was obtained. Reasons for bronchoscopy included investigation of a pulmonary shadow, ${ }^{12}$ unresolved pneumonia, ${ }^{4}$ haemoptysis, ${ }^{8}$ and pleural effusion. ${ }^{6}$ Clinical evidence of chronic bronchitis was present in 15 patients and bronchiectasis in one patient. There were three groups of 10 patients receiving either $250 \mathrm{mg}, 500 \mathrm{mg}$, or $1000 \mathrm{mg}$ doses of cefaclor at intervals of eight hours. The morning and afternoon doses on the days before bronchoscopy were taken 30 minutes before food. The patients fasted from midnight before bronchoscopy. The number of doses received by each patient before bronchoscopy ranged from four to 12 . Preparation for bronchoscopy commenced 30 minutes after the morning cefaclor dose with administration of the local anaesthetic, $10 \mathrm{ml}$ of viscous xylocaine as a mouth gargle and $5 \mathrm{ml}$ of $4 \%$ topical xylocaine as a cricothyroid membrane injection. The bronchoscope (Olympus BF type B3R) was passed through the mouth into the tracheobronchial tree and $\mathbf{4 5}$ minutes after the cefaclor dose five to eight bron- 
chial mucosal biopsy specimens were taken from main, lobar, or segmental bronchi unaffected by obvious disease. A venous blood sample was taken after the biopsies, 60 minutes after the cefaclor dose. Bronchial brushings, biopsy, or bronchoalveolar lavage were then carried out if indicated. Bronchial secretions, if present, were aspirated for cytological and microbiological examination.

\section{SPECIMEN PREPARATION}

Serum was stored at $-20^{\circ} \mathrm{C}$ until immediately before assay, when it was diluted tenfold in 1:1 v/v antibiotic free pooled human serum and $0.1 \mathrm{~mol} / \mathrm{l}$ phosphate buffer at $\mathrm{pH}$ 6.0. Bronchial mucosal tissue was collected into preweighed $2 \mathrm{ml}$ plastic analyser cupules with cap and transported immediately to the laboratory. The cupule was sealed to prevent weight loss by desiccation. It was then reweighed correct to $0.1 \mathrm{mg}$ and the weight of the bronchial mucosa was determined by the difference. The mean weight of tissue from each patient was $9.8 \mathrm{mg}$ (range $3.6-14.7 \mathrm{mg}$ ), and as each specimen contained five to eight biopsy samples each biopsy sample weighed less than $2 \mathrm{mg}$. We had decided to discard any biopsy sample which was macroscopically bloodstained and then to reassess the weight of the tissue. This was necessary on only one occasion. All bronchial mucosal specimens were homogenised in a Wheaton microtissue grinder in $0.1 \mathrm{~mol} / 1$ phosphate buffer, pH 6.0 , to a final volume of $0.3 \mathrm{ml}$, and stored at $-20^{\circ} \mathrm{C}$ until assayed. Less than 15 minutes elapsed between specimen collection and storage of the homogenate at $-20^{\circ} \mathrm{C}$. The rapid transfer of specimens to $\mathrm{a}-20^{\circ} \mathrm{C}$ environment was necessary because of the poor stability of the antibiotic when exposed to unfavourable conditions of temperature, $\mathrm{pH}$, or protein. ${ }^{2310}$

\section{ASSAY PROCEDURE}

The concentration of cefaclor in serum and bronchial mucosal homogenate was determined by a microbiological agar disc diffusion assay, Sarcina lutea ATCC 9341 being used as the test organism. The agar, $100 \mathrm{ml}$ of antibiotic medium No $1 \mathrm{pH} 6.5$ (Oxoid Ltd, London), was seeded with Sarcina lutea to a concentration of $2 \times 10^{6}$ colony forming units per $\mathrm{ml}$ and poured into $23 \mathrm{~cm}$ square Nunc-Bio assay plates (A/S Nunc, Roskilde, Denmark). Standard concentrations of cefaclor, batch No 51-1059C, activity $961 \mu \mathrm{g} / \mathrm{mg}$ (Eli Lilly and Co), were prepared in 1:1 v/v antibiotic free pooled human serum and $0.1 \mathrm{~mol} / 1$ phosphate buffer $\mathrm{pH} 6.0$ immediately before each assay in the range $0 \cdot 125-2.0 \mu \mathrm{g} / \mathrm{ml}$ from aliquots of a stock solution $\left(10^{4} \mu \mathrm{g} / \mathrm{ml}\right)$ stored at $-20^{\circ} \mathrm{C}$. All assays were performed in duplicate. From each specimen $100 \mu$ l was loaded on to a standard $12.7 \mathrm{~mm}$ diameter assay disc (Schleicher and Shuell Inc), which was then transferred to the assay plate by forceps. After prediffusion at $4^{\circ} \mathrm{C}$ for 30 minutes the assay plate was incubated at $37^{\circ} \mathrm{C}$ for 18-24 hours. Zone sizes were measured by Vernier calipers correct to $0 \cdot 1 \mathrm{~mm}$ and regression analysis was used to calculate the unknown cefaclor concentrations. The sensitivity of the assay was limited to $0.063 \mu \mathrm{g} / \mathrm{ml}$.

\section{Results}

Serum and bronchial mucosal cefaclor concentrations, bronchial mucosal biopsy sample weights, and

Table 1 Number of doses received, the individual and mean (SD) bronchial mucosal weights, serum and bronchial mucosal cefaclor concentrations, and the lower limits of detection for the bronchial concentrations in 10 patients receiving $250 \mathrm{mg}$ cefaclor orally before bronchoscopy

\begin{tabular}{|c|c|c|c|c|c|}
\hline \multirow{2}{*}{$\begin{array}{l}\text { Patient } \\
\text { No }\end{array}$} & \multirow{2}{*}{$\begin{array}{l}\text { No of } \\
\text { doses }\end{array}$} & \multirow{2}{*}{$\begin{array}{l}\text { Biopsy weight } \\
\text { (mg) }\end{array}$} & \multicolumn{2}{|c|}{ Cefaclor concentration $(\mu g / m l)$} & \multirow{2}{*}{$\begin{array}{l}\text { Lower limit of } \\
\text { detection* for } \\
\text { bronchial concentration } \\
(\mu g / g)\end{array}$} \\
\hline & & & Serum & Bronchial mucosa & \\
\hline $\begin{array}{r}1 \\
2 \\
3 \\
4 \\
5 \\
6 \\
7 \\
8 \\
9 \\
10\end{array}$ & $\begin{array}{r}4 \\
10 \\
6 \\
6 \\
6 \\
4 \\
12 \\
4 \\
4 \\
6\end{array}$ & $\begin{array}{r}12.8 \\
14.7 \\
10.8 \\
9.6 \\
10.0 \\
11.3 \\
14.3 \\
6.9 \\
8.2 \\
8.9\end{array}$ & $\begin{array}{l}2 \cdot 5 \\
1 \cdot 5 \\
0.5 \\
4 \cdot 3 \\
0.5 \\
3 \cdot 9 \\
5 \cdot 7 \\
1 \cdot 3 \\
0.5 \\
2.6\end{array}$ & $\begin{array}{l}2 \cdot 1 \\
\text { ND } \\
\text { ND } \\
4 \cdot 7 \\
\text { ND } \\
5 \cdot 8 \\
\text { ND } \\
\text { ND } \\
\text { ND } \\
2 \cdot 5\end{array}$ & $\begin{array}{l}1.5 \\
1.3 \\
1.7 \\
1.9 \\
1.9 \\
1.7 \\
1.3 \\
2.7 \\
2.3 \\
2.1\end{array}$ \\
\hline \multicolumn{2}{|c|}{$\begin{array}{l}\text { Mean (SD) } \\
n\end{array}$} & $\begin{array}{l}10 \cdot 75(2 \cdot 57) \\
10\end{array}$ & $\begin{array}{l}2.33(1.81) \\
10\end{array}$ & $\begin{array}{l}3 \cdot 78(1 \cdot 77) \\
4\end{array}$ & $\begin{array}{l}1.84(0.44) \\
10\end{array}$ \\
\hline
\end{tabular}

ND-not detected.

${ }^{*}$ Lower limit of detection for bronchial level $=$ final volume of biopsy material $(0.3 \mathrm{ml}) \times$ lower limit of assay sensitivity $(0.063 \mu \mathrm{g} / \mathrm{ml})$ weight of biopsy material 
Table 2 Number of doses received, the individual and mean (SD) bronchial mucosal weights, serum and bronchial mucosal cefaclor concentrations, and the lower limits of detection for the bronchial concentrations in 10 patients receiving $500 \mathrm{mg}$ cefaclor orally before bronchoscopy

\begin{tabular}{|c|c|c|c|c|c|}
\hline \multirow{2}{*}{$\begin{array}{l}\text { Patient } \\
\text { No }\end{array}$} & \multirow{2}{*}{$\begin{array}{l}\text { No of } \\
\text { doses }\end{array}$} & \multirow{2}{*}{$\begin{array}{l}\text { Biopsy weight } \\
\text { (mg) }\end{array}$} & \multicolumn{2}{|c|}{ Cefaclor concentration $(\mu \mathrm{g} / \mathrm{ml})$} & \multirow{2}{*}{$\begin{array}{l}\text { Lower limit of } \\
\text { detection* for } \\
\text { bronchial concentration } \\
(\mu g / g)\end{array}$} \\
\hline & & & Serum & Bronchial mucosa & \\
\hline $\begin{array}{l}11 \\
12 \\
13 \\
14 \\
15 \\
16 \\
17 \\
18 \\
19 \\
20\end{array}$ & $\begin{array}{l}5 \\
5 \\
4 \\
4 \\
6 \\
4 \\
4 \\
4 \\
4 \\
4\end{array}$ & $\begin{array}{r}6.0 \\
5.8 \\
5.0 \\
5.1 \\
10.4 \\
13.6 \\
13.6 \\
13.3 \\
8.7 \\
8.2\end{array}$ & $\begin{array}{r}22.0 \\
7.8 \\
13.8 \\
10.1 \\
5.0 \\
10.7 \\
3.7 \\
13.5 \\
0.9 \\
8.9\end{array}$ & $\begin{array}{l}3 \cdot 5 \\
4 \cdot 1 \\
\text { ND } \\
7 \cdot 1 \\
2 \cdot 0 \\
5 \cdot 5 \\
2 \cdot 4 \\
7 \cdot 4 \\
\text { ND } \\
3 \cdot 4\end{array}$ & $\begin{array}{l}3 \cdot 1 \\
3 \cdot 2 \\
3 \cdot 7 \\
3 \cdot 7 \\
1 \cdot 8 \\
1 \cdot 4 \\
1 \cdot 4 \\
1 \cdot 4 \\
2 \cdot 2 \\
2 \cdot 3\end{array}$ \\
\hline $\begin{array}{l}\text { Mean (SD) } \\
\mathrm{n}\end{array}$ & & $\begin{array}{l}8 \cdot 97(3 \cdot 56) \\
10\end{array}$ & $\begin{array}{l}9.64(5.99) \\
10\end{array}$ & $\begin{array}{l}4 \cdot 43(2 \cdot 04) \\
8\end{array}$ & $10.42(0.94)$ \\
\hline
\end{tabular}

ND-not detected.

* See table 1 .

the number of cefaclor doses received by each patient are shown for the three doses in tables 1-3. The lower limit of detection for the bronchial mucosal concentrations, a function of the original biopsy sample weight, is also shown. Serum concentrations for both the $1000 \mathrm{mg}$ and the $500 \mathrm{mg}$ doses were significantly higher than for the $250 \mathrm{mg}$ doses ( $p<0.005$ ), but there was no significant difference between the $1000 \mathrm{mg}$ and $500 \mathrm{mg}$ doses. Bronchial mucosal concentrations for the $1000 \mathrm{mg}$ doses were significantly higher than for the $500 \mathrm{mg}(\mathrm{p}<0.025)$ and $250 \mathrm{mg}$ doses $(\mathrm{p}<0.05)$, but there was no significant difference between the $500 \mathrm{mg}$ and 250 mg doses. In 12 cases no cefaclor was detected in the bronchial mucosa (six had received $250 \mathrm{mg}$, two 500 $\mathrm{mg}$, and four $1000 \mathrm{mg}$ doses). Of these, $10 \mathrm{had}$ serum concentrations less than $2.0 \mu \mathrm{g} / \mathrm{ml}$. One patient developed mild diarrhoea after two $1000 \mathrm{mg}$ doses (No 22: table 3), but otherwise no other unwanted effects were reported.

\section{Discussion}

The bronchial mucosa is the site of infection in acute exacerbations of chronic bronchitis. " Eradication of infection will depend on the antibiotic concentrations achieved in the bronchial mucosa as well as on natural defence mechanisms. Few studies have examined antibiotic levels in vivo in human lung and bronchial tissue..$^{12-14}$ Recently lung tissue concentra-

Table 3 Number of doses received, the individual and mean (SD) bronchial mucosal weights, serum and bronchial mucosal cefaclor concentrations, and the lower limits of detection for the bronchial concentrations in 10 patients receiving $1000 \mathrm{mg}$ cefaclor orally before bronchoscopy

\begin{tabular}{|c|c|c|c|c|c|}
\hline \multirow{2}{*}{$\begin{array}{l}\text { Patient } \\
\text { No }\end{array}$} & \multirow{2}{*}{$\begin{array}{l}\text { No of } \\
\text { doses }\end{array}$} & \multirow{2}{*}{$\begin{array}{l}\text { Biopsy weight } \\
\text { (mg) }\end{array}$} & \multicolumn{2}{|c|}{ Cefaclor concentration $(\mu g / m l)$} & \multirow{2}{*}{$\begin{array}{l}\text { Lower limit of } \\
\text { detection* for } \\
\text { bronchial concentration } \\
(\mu \mathrm{g} / \mathrm{g})\end{array}$} \\
\hline & & & Serum & Bronchial mucosa & \\
\hline $\begin{array}{l}21 \\
22 \\
23 \\
24 \\
25 \\
26 \\
27 \\
28 \\
29 \\
30\end{array}$ & $\begin{array}{l}6 \\
4 \\
4 \\
4 \\
4 \\
4 \\
9 \\
6 \\
9 \\
6\end{array}$ & $\begin{array}{r}7.2 \\
12.5 \\
6.3 \\
12.8 \\
9.9 \\
7.9 \\
10.6 \\
12.0 \\
12.9 \\
3.6\end{array}$ & $\begin{array}{r}1.2 \\
13.2 \\
24.6 \\
15.5 \\
29.2 \\
1.7 \\
27 \cdot 1 \\
0.7 \\
\text { ND } \\
19.7\end{array}$ & $\begin{array}{c}\text { ND } \\
5 \cdot 0 \\
7 \cdot 2 \\
5 \cdot 4 \\
7 \cdot 9 \\
\text { ND } \\
12 \cdot 7 \\
\text { ND } \\
\text { ND } \\
\mathbf{8 \cdot 2}\end{array}$ & $\begin{array}{l}2.6 \\
1.5 \\
3.0 \\
1.5 \\
1.9 \\
2.4 \\
1.8 \\
1.6 \\
1.5 \\
5.2\end{array}$ \\
\hline $\begin{array}{l}\text { Mean (SD) } \\
\mathbf{n}\end{array}$ & & $\begin{array}{l}9.57(3.20) \\
10\end{array}$ & $\begin{array}{l}14 \cdot 77(11 \cdot 39) \\
9\end{array}$ & $\begin{array}{l}7 \cdot 73(2 \cdot 76) \\
6\end{array}$ & $\begin{array}{l}2 \cdot 30(1 \cdot 15) \\
10\end{array}$ \\
\hline
\end{tabular}

ND-not detected.

* See table 1 . 
tions of erythromycin have been measured in patients with lobar pneumonia by the technique of positron tomography. ${ }^{15}$ There have been many studies of sputum antibiotic concentrations, ${ }^{16}$ but bronchial tissue concentration can be inferred only by assuming that a gradient of antibiotic concentration exists from blood through bronchial mucosa to bronchial secretions. We have previously studied bronchial mucosal antibiotic concentrations by obtaining tissue at fibreoptic bronchoscopy. ${ }^{17}$ This method has the advantage of providing bronchial mucosal specimens which are uncontaminated by blood. We consider that measurement of antibiotic concentration in bronchial secretions collected at bronchoscopy may be unreliable because of possible dilution and contamination by the local anaesthetic, which may also inhibit subsequent bacterial growth in the assay procedure. Some patients have only a small volume of secretions, requiring the addition of saline for collection, but the dilutional factor cannot be determined accurately.

The mean bronchial cefaclor concentration was $3.78 \mu \mathrm{g} / \mathrm{g}$ (range $2.1-5.8 \mu \mathrm{g} / \mathrm{g}$ ) for the $250 \mathrm{mg}$ doses, $4.43 \mu \mathrm{g} / \mathrm{g}$ (range $2 \cdot 0-7 \cdot 1 \mu \mathrm{g} / \mathrm{g}$ ) for the $500 \mathrm{mg}$ doses, and $7.73 \mu \mathrm{g} / \mathrm{g}$ (range 5.0 to $12.7 \mu \mathrm{g} / \mathrm{g}$ ) for the 1000 mg doses. A significantly higher bronchial mucosal concentration was achieved with the $1000 \mathrm{mg}$ doses than with the 250 or $500 \mathrm{mg}$ doses. Cefaclor was not always detected in the bronchial mucosal specimens but this does not imply that no antibiotic was present. The weight of bronchial tissue in the biopsy specimen determines the lower limit of detection. A low weight of biopsy material may impose limitations on the use of the technique if the therapeutic range of the antibiotic is near the lower limit of detection. In 10 patients in whom cefaclor was undetectable in the bronchial biopsy material serum levels were also low and this was observed with all doses. In the fasting state concentrations near peak levels would have been expected one hour after administration of the dose, as has been reported in healthy subjects. ${ }^{18-20}$ Food is known to delay absorption and to reduce peak concentrations of cefaclor, ${ }^{20}$ but this was not a factor in this study. In patients in hospital there are other reasons for delayed or incomplete absorption; these include immobility, age, and disease. Peak serum concentrations have been shown to be variable and delayed in patients with renal insufficiency. ${ }^{21}$ In this study the finding of corresponding low serum and bronchial mucosal cefaclor concentrations suggests that incomplete absorption occurred in 10 of the 30 patients. As a result there is a tendency for the mean serum concentrations obtained with the three doses to be lower than those reported in healthy subjects. $^{18-20}$ There are no detailed pharmacokinetic studies of cefaclor in hospitalised patients to assess absorption characteristics.

In this study bronchial mucosal concentrations are much higher than those found in sputum..$^{21} 22$ Levison $e$ t $a l^{21}$ found a mean concentration of $0.6 \mu \mathrm{g} / \mathrm{ml}$ (range $0 \cdot 3-1 \cdot 1 \mu \mathrm{g} / \mathrm{ml}$ ) in six bronchitic patients, but failed to detect it at all in another four patients after $1000 \mathrm{mg}$ cefaclor. Simon and Gatzemeier ${ }^{22}$ found in bronchitic patients mean peak concentrations of 0.44 (first day) and $0.54 \mu \mathrm{g} / \mathrm{ml}$ (third day) when 500 $\mathrm{mg}$ cefaclor was taken four times daily and 0.57 (first day) and $0.54 \mu \mathrm{g} / \mathrm{ml}$ (third day) with $1000 \mathrm{mg}$ four times daily, these sputum concentrations being 8-10\% of serum levels. Cefaclor may show instability in bronchial secretions in vivo related to temperature, $\mathrm{pH}$, or the protein content.

Microbiological studies of sensitivity to cefaclor have indicated that the minimal inhibitory concentration (MIC) of $S$ pneumoniae ranges from 0.5 to $4.0 \mu \mathrm{g} / \mathrm{ml}$, most strains being inhibited below 1.0 $\mu \mathrm{g} / \mathrm{ml}^{1{ }^{1310}}$ A wide range of susceptibility to $H$ infuenzae has been reported, MICs ranging from 0.5 to $16.0 \mu \mathrm{g} / \mathrm{ml}$ for ampicillin sensitive strains with most inhibited below $4.0 \mu \mathrm{g} / \mathrm{ml}$, and from 0.5 to 64 $\mu \mathrm{g} / \mathrm{ml}$ for ampicillin resistant or $\beta$-lactamase producing strains with most inhibited below $16.0 \mu \mathrm{g} / \mathrm{ml} .^{126}$ The bronchial mucosal concentrations achieved in this study by patients with appropriate serum concentrations should be effective against $S$ pneumoniae with all doses used. The concentrations are within one dilution of the MIC for $H$ infuenzae so that not all strains will be inhibited, particularly ampicillin resistant strains. This also applies for Gram negative organisms, which may be implicated in patients with severe bronchial disease-for example, $K$ pneumoniae, $E$ coli $\left(\mathrm{MIC}<8.0 \mu \mathrm{g} / \mathrm{ml}^{12}\right.$ ). Ultimately the efficacy of an antibiotic for these infections can be assessed only by the clinical response of the patient. The results of this work indicate the need for further studies of efficacy and bioavailability in patients with bronchial infection.

We wish to thank Lilly Industries Pty Ltd, Australia, for their support and supply of drugs, and $\mathrm{Dr} \mathrm{HO}$ Wooller, medical director, for his helpful assistance.

\section{References}

' Bill NJ, Washington JA. Comparison of in vitro activity of cephalexin, cephradine, and cefaclor. Antimicrob Agents Chemother 1977;11:470-4.

${ }^{2}$ Sanders CC. In vitro studies with cefaclor, a new cephalosporin. Antimicrob Agents Chemother 1977;12:490-7.

${ }^{3}$ Preston DA. Summary of laboratory studies on the antibacterial activity of cefaclor. Postgrad Med J $1979 ; 55$,suppl 4:22-9. 
${ }^{4}$ May JR. Chemotherapy of chronic bronchitis and allied disorders. 2nd ed. London: English Universities Press, 1972.

${ }^{5}$ Philpott-Howard J, Williams JD. Increase in antibiotic resistance in Haemophilus infuenzae in the United Kingdom since 1977: report of study group. $\mathrm{Br} \mathrm{Med} \mathrm{J}$ 1982; 284: 1597-9.

- Neu HC, Fu KP. Cefaclor: in vitro spectrum of activity and beta-lactamase stability. Antimicrob Agents Chemother 1978;13:584-8.

${ }^{7}$ Mattson K, Renkonen O-V, Laitinen L, NikanderHurme R. Treatment of acute bronchitis and pneumonia with cefaclor. Postgrad Med J 1979;55,suppl 4:59-61.

${ }^{8}$ Mogabgab WJ, Pollock B, Beville RB, Gentry LO, Jemsck JG. Treatment of acute bacterial bronchitis and pneumonia with cefaclor. Postgrad Med J 1979;55,suppl 4:62-4.

${ }^{9}$ Wernstedt I, Berntsson E, Thiringer G. Cefaclor therapy in acute exacerbations of chronic bronchitis. Postgrad Med J 1979;55,suppl 4:56-8.

${ }^{10}$ Gillett AP, Andrews JM, Wise R. Comparative in vitro microbiological activity and stability of cefaclor. Postgrad Med J 1979;55,suppl 4:9-11.

"Hers JGP, Mulder J. The mucosal epithelium of the respiratory tract in mucopurulent bronchitis caused by Haemophilus infuenzae. J Path Bacteriol 1953;66:103-8.

${ }^{12}$ Liss RH, Norman JC. Visualisation of doxycycline in lung tissue and sinus secretions by fluorescent techniques. Chemother 1975;21:27-35.

${ }^{13}$ Gartmann J. Doxycycline concentrations in lung tissue, bronchial wall and bronchial secretions. Chemother 1975;21:19-26.

${ }^{14}$ Kroening U, Liebig S, Windschock M. Tobramycin concentrations in human lung tissue. A study of 30 intravital lung tissue samples. Infection 1978;6:231-5.

is Wollmer P, Pride NB, Rhodes CG, Sanders A, Pike VW, Palmer AJ, Silvester DJ, Liss RH. Measurement of pulmonary erythromycin concentration in patients with lobar pneumonia by means of positron tomography. Lancet 1982;ii:1361-4.

${ }^{16}$ Smith BR, LeFrock JL. Bronchial tree penetration of antibiotics. Chest 1983;83:904-8.

${ }^{17}$ Marlin GE, Burgess KR, Burgoyne J, Funnell GR, Guinness MDG. Penetration of piperacillin into bronchial mucosa and sputum. Thorax 1981;36:774-80.

${ }^{18}$ Korzeniowski OM, Scheld WM, Sande MA. Comparative pharmacology of cefaclor and cephalexin. Antimicrob Agents Chemother 1977;12:157-62.

${ }^{19}$ Hodges GR, Liu C, Hinthorn DR, Harms JL, Dworzack DL. Pharmacological evaluation of cefaclor in volunteers. Antimicrob Agents Chemother 1978;14:454-6.

${ }^{20}$ Santoro J, Agarwal BN, Martinelli R, Wenger N, Levison ME. Pharmacology of cefaclor in normal volunteers and patients with renal failure. Antimicrob Agents Chemother 1978;13:951-4.

${ }^{21}$ Levison ME, Santoro J, Agarwal BN. In vitro activity and pharmacokinetics of cefaclor in normal volunteers and patients with renal failure. Postgrad Med J 1979;55,suppl 4:12-6.

${ }^{22}$ Simon C, Gatzemeier U. Serum and sputum levels of cefaclor. Postgrad Med J 1979;55,suppl 4:30-4. 